\title{
MANAJEMEN LABA: PRO-KONTRA PEMAKNAAN ANTARA KREDITUR DAN DEBITUR DALAM PROSES PEMBIAYAAN KREDIT
}

\author{
Anggie Febriyanti \\ Tjiptohadi Sawarjuwono \\ Bram Ade Pratama \\ Fakultas Ekonomi Bisnis Universitas Airlangga \\ Jl. Airlangga 4-6, Surabaya 60286 \\ Email: tjiptohadi_unair@yahoo.co.uk
}

\begin{abstract}
Abstrak
Manajemen laba menjadi topik pembahasan yang menarik. Salah satu pemikirannya yaitu selama dilakukan sesuai dengan Standar Akuntansi Keuangan Indonesia sulit dikatakan sebagai manajemen laba. Namun demikian, akuntan cenderung memanfaatkan perlakuan akuntansi untuk memenuhi kepentingan tertentu. Sebaliknya, kreditur, dalam pengambilan keputusan pembiayaannya tidak semata-mata mempertimbangkan terjadi atau tidaknya manajemen laba, tetapi menggunakan berbagai teknik analisa lain yang lebih komprehensif. Penelitian ini menerapkan unobtrusive observation. Dengan penelitian secara tersembunyi, dapat diungkap terjadinya manajemen laba serta berbagai pertimbangan debitur maupun kreditur dalam menyikapinya.
\end{abstract}

Kata Kunci: Manajemen Laba, Unobtrusive Observation, Pertimbangan Kreditur-Debitur

\begin{abstract}
Earnings management has been a hot topic. As long as along with the Indonesian Financial Accounting Standard, this cannot be considered as earnings management. However, the accountants tend to apply the particular treatment to meet their specific interests. The creditors do not consider whether there is earnings management, but they will apply many other more comprehensive evaluation techniques. This study applied unobtrusive observation. By doing this, the researchers were able to uncover the existing earnings management as well as the variety of debtors' and creditors' considerations.
\end{abstract}

Keywords: Earnings Management, Unobtrusive Observation, Debtors' and Creditors' Considerations

\section{PENDAHULUAN}

Dalam menyusun sebuah laporan keuangan, akuntan tidak dapat dilepaskan dari subyektivitasnya (Jusuf, 2010). Praktik manajemen laba (earnings management) telah menjadi isu dan fenomena umum di Indonesia (Leuz et al., 2003). Hal demikian nampaknya cenderung selalu terjadi, mengingat akuntan dalam perusahaan mempunyai tujuan khusus (Scott, 2006) atau karena intervensi manajemen (Schipper, 1989). Hal ini dimungkinkan karena akuntan memiliki kesempatan, kekuasaan dan pengetahuan untuk mengatur seberapa besar laba yang diinginkan. Selain itu, manajemen laba dimungkinkan pula oleh Standar Akuntansi Keuangan (SAK). Dalam hal ini akuntan dapat mempengaruhi angka laba melalui pemilihan metode atau kebijakan akuntansi yang diperbolehkan dalam SAK.

Terjadi atau tidaknya praktik manajemen laba telah diteliti oleh berbagai peneliti, diantaranya
Dechow \& Skinner (2000), Gosh (2010), Palliam \& Shalhoub (2003), Riduwan (2010), Sharma et al. (2011). Dechow \& Skinner (2000) dan Riduwan (2010) menjelaskan hal yang serupa, yaitu adanya sikap pro dan kontra atas praktik ini. Hasilnya mengungkapkan bahwa pihak yang pro memandang bahwa manajemen laba boleh dilakukan dan bukan merupakan perilaku koruptif sepanjang dilakukan dalam koridor prinsip akuntansi berterima umum. Sebaliknya, pihak yang kontra menyatakan bahwa manajemen laba tidak berbeda dengan tindakan memanipulasi laba.

Demikian pula yang dilakukan oleh Gosh (2010), dengan istilah creative accounting, didapati bahwa praktik ini menyebabkan collapse-nya beberapa perusahaan international. Sejalan dengan beragamnya kasus praktik tersebut, Palliam \& Shalhoub (2003) menemukan salah satu tekniknya yaitu dengan cara penundaan transaksi yang berakibat pada nilai besaran laba. Sharma et al. (2011) meneliti bagai- 
mana peran audit committee dalam upaya melakukan penekanannya karena memang diyakini praktik manajemen laba ini terjadi.

Studi lain yang dilakukan oleh DeFond \& Jiambalvo (1994), Sweeney (1994), Peltier-Rivest (1999), Jaggi \& Lee (2001), dan Rosner (2003) memberikan bukti mengenai pola manajemen laba dalam bentuk meningkatkan laba. Sementara itu DeAngelo et al. (1994) dan Saleh \& Ahmed (2005) menemukan bahwa manajer lebih mungkin melakukannya dengan teknik menurunkan laba. Di Indonesia terdapat juga beberapa penelitian yang hasilnya serupa dengan hasil tersebut di atas, yaitu yang dilakukan oleh Kusumawati \& Sasongko (2005), Syam (2004), Andriyani (2004), dan Djakman (2003).

Terkait proses pembiayaan perusahaan, kreditur akan sangat peduli terhadap besaran angka laba yang dilaporkan dalam laporan keuangan perusahaan. Laporan keuangan bagi kreditur merupakan alat analisis kuantitatif. Kreditur cenderung lebih fokus pada laba dalam membaca informasi pada laporan keuangan. Laba merupakan ukuran kinerja sebuah entitas (Schroeder \& Clark, 1998; Ikatan Akuntan Indonesia, 2009) yang dianggap sebagai informasi utama dalam laporan keuangan (Lev, 1989), dan mempunyai nilai prediktif (Horrigan, 1965; Beaver, 1966; Altman, 1968; Brigham \& Gapenski, 1993). Oleh karena itu, kreditur selalu memperhatikan besaran dan pencapaian laba (Sutojo, 2000; Suyatno 1993).

Akuntan termotivasi untuk melakukan manajemen laba dalam rangka mencapai kinerja yang ditargetkan sesuai dengan perjanjian pembiayaan antara perusahaan dengan kreditur. Namun demikian, mengingat keyakinan akan adanya praktik manajemen laba, maka salah satu hal yang akan menjadi perhatian kreditur adalah adanya kemungkinan terjadinya hal tersebut di atas. Perbedaan ekspektasi debitur dan kreditur atas peran laporan keuangan menjadi daya tarik, sehingga penelitian ini akan menganalisis lebih mendalam peran debitur maupun kreditur mengenai masalah ada atau tidaknya manajemen laba.

Rumusan masalah penelitian ini adalah bagaimana kreditur mempertimbangkan kemungkinan terjadinya manajemen laba dalam kaitan dengan proses pengajuan pembiayaan. Di satu sisi, kreditur menginginkan laporan keuangan yang handal dan relevan guna membantu evaluasi pertimbangan pemberian serta menaksir besarnya risiko kredit. Di lain sisi, debitur menyusun laporan keuangan didorong motivasi untuk mendapatkan persetujuan atas pengajuan kredit pembiayaannya. Melalui penelitian ini diharapkan dapat memberikan pemahaman yang lebih komprehensif atas manajemen laba dalam dua perspektif, kondisi aktual dengan kondisi ideal yang seharusnya terjadi, yaitu dari sisi kreditur dan debitur sesuai dengan posisi dan kepentingan masing-masing.
Dengan mempertimbangkan masalah kerahasiaan (hiden activities), dalam hal ini kesempatan mengungkap kejadian yang sebenarnya secara komprehensif serta adanya kesempatan akses sebebasnya ke dalam obyek penelitian, maka peneliti menerapkan unobtrusive observation (Alison et al., 2001). Dengan metode ini, diharapkan mampu mengobservasi secara tersembunyi data asli, mempunyai kesempatan berinteraksi langsung dengan pelaku, sekaligus melakukan wawancara mendalam, baik dari sisi debitur maupun kreditur, sehingga memperoleh data yang sangat relevan.

Standar akuntansi yang ditetapkan oleh Ikatan Akuntan Indonesia (IAI) mengijinkan pihak manajemen untuk mengambil suatu kebijakan dalam mengaplikasikan metode akuntansi guna menyampaikan informasi mengenai kinerja perusahaan kepada pihak ekstern. Pemberian fleksibilitas bagi manajemen untuk memilih satu dari seperangkat kebijakan akuntansi membuka peluang untuk perilaku oportunis dan kontrak efisien. Dengan kata lain, manajer yang rasional, akan memilih kebijakan akuntansi yang sesuai dengan kepentingannya. Perilaku oportunis dan kontrak efisien ini, mendorong manajer untuk melakukan manajemen laba.

\section{LANDASAN TEORI}

\section{Makna Manajemen Laba}

Healy \& Wahlen (1999), menyatakan bahwa definisi manajemen laba mengandung beberapa aspek. Pertama, intervensi manajemen laba terhadap pelaporan keuangan dapat dilakukan dengan penggunaan judgment, misalnya judgment yang dibutuhkan dalam mengestimasi sejumlah peristiwa ekonomi di masa depan untuk ditunjukkan dalam laporan keuangan. Kedua, tujuan manajemen laba untuk menyesatkan penggunanya mengenai kinerja ekonomi perusahaan. Hal ini muncul ketika manajemen memiliki akses terhadap informasi yang tidak dapat diakses oleh pihak luar. Definisi yang lain menyebutkan bahwa manajemen laba adalah "disclosure management" dalam arti intervensi yang disengaja pada proses pelaporan keuangan kepada pihak eksternal yang tujuannya untuk mendapatkan keuntungan pribadi, kebalikan dari melakukan faktualisasi proses operasi yang normal (Schipper, 1989).

Sugiri (1998) membagi definisi manajemen laba menjadi dua, yaitu:

1) Definisi Sempit

Manajemen laba dalam hal ini hanya berkaitan dengan pemilihan metode akuntansi. Manajemen laba dalam artian sempit ini didefinisikan sebagai 
prilaku manajer untuk "bermain" dengan komponen discretionary accruals dalam menentukan besarnya earnings.

2) Definisi Luas

Manajemen laba merupakan tindakan manajer untuk meningkatkan (mengurangi) laba yang dilaporkan saat ini atas suatu unit di mana manajer bertanggung jawab, tanpa mengakibatkan peningkatan (penurunan) profitabilitas ekonomis jangka panjang unit tersebut.

Lain halnya dengan pendapat Surifah (1999). Dia mengungkapkan bahwa manajemen laba dapat mengurangi kredibilitas laporan keuangan apabila digunakan untuk pengambilan keputusan, karena manajemen laba merupakan suatu bentuk manipulasi atas laporan keuangan yang menjadi sarana komunikasi antara manajer dan pihak eksternal perusahaan. Mengacu pada pendapat Sugiri (1998) dan Surifah (1999) di atas, maka manajemen laba dinyatakan dalam perspektif opurtinistis. Pada umumnya studi tentang manajemen laba dinyatakan dalam perspektif oportinistis dibandingkan perspektif efisiensi. Perspektif efisiensi menyatakan bahwa manajer melakukan pilihan atas kebijakan akuntansi untuk memberikan informasi yang lebih baik cash flow yang akan datang dan untuk meminimalkan agency cost yang terjadi karena konflik kepentingan antara stakeholder dan manajer (Jiambalvo, 1996).

Dari berbagai perspektif, beberapa penulis memaknai manajemen laba secara berbeda. Schroeder \& Clark (1998) mengartikan manajemen laba (earnings management) sebagai upaya-upaya manajemen untuk mempengaruhi laba bersih yang dilaporkan saat ini. Secara lebih tegas, Fischer \& Rosenzweig (1995) mengartikan manajemen laba sebagai tindakan-tindakan manajer yang dimaksudkan untuk memperbesar atau memperkecil laba bersih yang dilaporkan sekarang tanpa menimbulkan kenaikan atau penurunan profitabilitas ekonomis perusahaan dalam jangka panjang. Definisi ini secara implisit memberikan gambaran bahwa manajemen laba sebenarnya hanyalah tindakan manajer untuk menggeser periode pengakuan laba, dengan cara memperbesar atau memperkecil laba yang diakui sekarang, tanpa mempengaruhi total laba atau profitabilitas perusahaan dalam jangka panjang. Berbeda dengan Fischer \& Rosenzweig (1995), Schipper (1989) mendefinisikan manajemen laba sebagai suatu intervensi yang disengaja pada proses pelaporan keuangan eksternal dengan maksud mendapatkan keuntungan pribadi.

Sependapat dengan Schipper (1989), Healy \& Wahlen (1999) menyatakan bahwa manajemen laba terjadi ketika para manajer menggunakan keputusannya dalam pelaporan keuangan dan dalam melakukan pencatatan transaksi untuk mengubah laporan keuangan, dengan tujuan untuk memberikan gambaran yang salah bagi penggunanya tentang kinerja ekonomis perusahaan, maupun untuk mempengaruhi hasil kontraktual yang bergantung pada angka-angka akuntansi yang dilaporkan.

Definisi yang diberikan oleh Schipper (1989) serta Healy \& Wahlen (1999) tersebut menunjukkan bahwa manajemen laba bukanlah sekedar menggeser periode pengakuan laba, tetapi mengarah pada upaya manajer untuk memberikan gambaran yang salah kepada para pengguna tentang kinerja perusahaan, sehingga keputusan yang akan diambil oleh para penggunanya sesuai dengan harapan manajemen. Pihak lain menyampaikan manajemen laba bukan seba-gai bentuk tindakan manipulasi laba apabila masih dilakukan dalam koridor prinsip akuntansi berterima umum (Schroeder \& Clark, 1998) dan Djakman (2003).

Scott (2006) mendefinisikan manajemen laba sebagai pemilihan kebijakan akuntansi oleh manajer dari Standar Akuntansi Keuangan yang ada dan secara alamiah dapat memaksimalkan utilitas dan atau nilai pasar perusahaan. Manajemen laba menurut Mulford \& Comiskey (2002), merupakan financial numbers game (permainan angka-angka keuangan) yang dilakukan melalui creative accounting practises akibat adanya kelonggaran flexibility principles yang dikeluarkan oleh GAAP (General Accepted Accounting Principal).

Dari uraian di atas dapat dilihat bahwa tidak ada definisi baku atas manejemen laba, namun jika dilihat dari pendapat-pendapat peneliti sebelumnya secara umum manajemen laba ialah tindakan manajer untuk mempengaruhi angka laba dalam laporan keuangan melalui pemilihan metode akuntansi didasari motivasi atau tujuan tertentu. Menurut peneliti sendiri, manajemen laba ialah campur tangan manajemen atas angka laba sesuai dengan kepentingan manajer dengan memanfaatkan peluang dari SAK yaitu kebebasan untuk memilih metode akuntansi.

\section{Pola Manajemen Laba}

Pola manajemen laba yang umum dilakukan oleh manajer adalah pola peningkatan laba (income increasing), penurunan laba (income decreasing) dan perataan laba (income smoothing) (Dechow \& Skinner 2000). Pola-pola manajemen laba tersebut dapat dicapai melalui strategi pemilihan keputusan operasi, investasi dan pembelanjaan yang tepat (McNichols \& Wilson, 1988), serta pemilihan teknik akuntansi yang dipandang srategis (Schroeder \& Clark, 1998). Keputusan operasi, investasi dan pembelanjaan sering tidak mampu memberikan hasil sesuai dengan harapan manajer meskipun keputusan tersebut dipandang telah optimum. Oleh karena itu, manajer beralih untuk memusatkan perhatiannya pada pemilihan teknik akuntansi yang dianggap efektif untuk mempengaruhi 
angka laba (Teoh et al., 1998). Praktik mempengaruhi angka laba dengan memanfaatkan teknik akuntansi ini antara lain adalah melalui manajemen akrual (accruals management), penerapan lebih awal atas standar akuntansi baru, dan perubahan kebijakan akuntansi (Ayres, 1994).

Fenomena manajemen laba seperti yang dikemukakan oleh Schipper (1989) serta Healy \& Wahlen (1999) ini pernah dikemukakan oleh Arthur Levitt, Ketua Stock Exchange Commision (SEC). Dalam pidatonya tanggal 28 September 1998, Arthur Levitt menggunakan istilah manajemen laba untuk mengacu pada usaha-usaha manajer perusahaan dalam memutar balikkan fakta ekonomi perusahaan yang sebenarnya dan melaporkan hasil yang dicapai oleh perusahaan sesuai dengan kepentingan manajemen. Levitt juga mengatakan bahwa saat ini telah terjadi erosi terhadap kualitas earnings, yang secara keseluruhan juga berarti terjadi erosi pada kualitas laporan keuangan. Berdasarkan fenomena ini pula semakin banyak keraguan dari pihak kreditur akan keandalan laporan keuangan dalam memberikan informasi atas kondisi dan kinerja ekonomi perusahaan.

Menurut Ayres (1994) manajemen laba dapat dilakukan oleh manajer dengan cara-cara sebagai berikut:

a. Manajemen akrual

Manajemen akrual biasanya dikaitkan dengan segala aktivitas yang dapat mempengaruhi aliran kas dan juga keuntungan yang secara pribadi merupakan wewenang dari para manajer (manager's discretion). Contoh manajemen akrual antara lain adalah dengan mempercepat atau menunda pengakuan akan pendapatan (revenue), menganggap sebagai ongkos (beban biaya) atau menganggap sebagai suatu tambahan investasi atas suatu biaya, dan perkiraan-perkiraan akuntansi lainnya, seperti: beban piutang ragu-ragu, dan perubahan-perubahan metode akuntansi.

b. Penerapan suatu kebijaksanaan akuntansi yang wajib

Terkait dengan penerapan suatu kebijaksanaan akuntansi yang wajib dilakukan oleh perusahaan, manajemen perusahaan memiliki dua pilihan, yaitu apakah menerapkan lebih awal dari waktu yang ditetapkan atau menundanya sampai saat berlakunya kebijaksanaan tersebut. Biasanya, untuk suatu kebijaksanaan akuntansi baru yang wajib, badan akuntansi yang ada memberikan kesempatan kepada perusahaan untuk dapat menerapkannya lebih awal dari waktu berlakunya. Para manajer tentu saja akan memilih untuk menerapkan suatu kebijaksanaan akuntansi yang baru bila dengan penerapan tersebut akan dapat mempengaruhi baik aliran kas maupun keuntungan perusahaan. c. Perubahan akuntansi secara suka rela

Dalam kaitannya dengan faktor yang ketiga, yaitu perubahan metode akuntansi secara suka rela, biasanya berkaitan dengan upaya manajer untuk mengganti atau merubah suatu metode akuntasi tertentu diantara sekian banyak metode yang dapat dipilih yang tersedia dan diakui oleh badan akuntansi yang ada

Dalam perbincangan manajemen laba seringkali mendorong munculnya kontroversi apakah manajemen laba sama dengan manipulasi laba. Menurut Djakman (2003) manajemen laba (earnings management) yang dilakukan melalui manajemen akrual tidak sama dengan manipulasi laba (earnings manipulation). Manajemen laba dilakukan untuk memenuhi kepentingan manajemen dengan memanfaatkan kelemahan inheren dari kebijakan akuntansi akrual dan masih berada dalam koridor prinsip akuntansi berterima umum. Sementara itu, manipulasi laba merupakan tindak pelanggaran terhadap prinsip akuntansi berterima umum untuk menghasilkan kinerja keuangan perusahaan sesuai kepentingan manajer atau perusahaan.

Senada dengan Djakman (2003), Schroeder \& Clark (1998) menyatakan bahwa apabila manajemen laba dilakukan atas dasar pertimbangan-pertimbangan manajerial yang sehat atau melalui pemilihan metode dan prosedur akuntansi dalam batas-batas yang diperbolehkan oleh standar akuntansi, manajemen laba bukanlah suatu tindak kecurangan (fraud), meskipun manajemen laba dengan cara-cara tersebut dapat mempengaruhi keputusan dari penggunanya.

Namun, tidak menutup kemungkinan bahwa manajemen laba dapat mengarahkan pada suatu tindak kecurangan (fraud). Manajemen laba dilakukan dengan cara yang salah, yang mana manajer secara sengaja menerapkan metode estimasi yang tidak masuk akal, serta memilih metode-metode akuntansi dan pelaporan keuangan yang tidak tepat, sehingga laporan keuangan tidak merefleksikan posisi ekonomi perusahaan yang sebenarnya. Tujuan kecurangan dari manajemen laba semacam ini tidak lain adalah mengelabui (mislead) para pengguna laporan keuangan (Healy \& Wahlen 1999).

Dalam konteks definisi yang diberikan oleh Fischer \& Rosenzweig (1995), praktik manajemen laba hanyalah upaya "mempermainkan" angka laba di atas kertas, dan tidak menimbulkan kerugian materi bagi siapa pun. Permainan angka laba di atas kertas ini dilakukan oleh manajer dengan memanfaatkan fleksibilitas standar akuntansi yang tersedia. Hal ini dimungkinkan karena standar akuntansi cukup memberikan peluang kepada manajer untuk mencatat fakta tertentu dengan cara yang berbeda, serta peluang untuk menggunakan subjektivitas dalam melakukan estimasi akuntansi (Worthy, 1984). 
Dengan demikian dapat dilihat bahwa batasan manajemen laba dan manipulasi laba menjadi tipis. Peluang dari standar akuntansi dan kebebasan untuk memilih metode akuntansi mendorong semakin longgarnya praktik manajemen laba. Secara umum masih banyak persepsi yang mengatakan bahwa manajemen laba bukanlah manipulasi laba selama dilakukan masih dalam koridor SAK.

\section{Evaluasi oleh Kreditur}

Dalam pertimbangan pemberian kredit, kreditur melakukan dua macam evaluasi, yaitu secara kuantitatif dan kualitatif. Secara kuantitatif yaitu menekankan pada evaluasi kinerja keuangan, diantaranya kemampuan perusahaan memperoleh laba (capacity) dan besaran modalnya (capital). Akan tetapi, semua itu juga dilakukan secara kualitatif, dengan mempertimbangkan secara komprehensif, yaitu menggunakan evaluasi Character (watak), Capacity (kemampuan), Capital (modal), Collateral (jaminan), Condition of Economy (kondisi ekonomi) (Suyatno, 1993). Bahkan kreditur juga selalu memperhatikan potensi perusahaan lainnya, yang disesuaikan dengan industri debitur, yaitu mengevaluasi physical environment, pro-cess, people, dan product (Kotler \& Keller, 2011) terkait dengan operasi bisnis perusahaan.

Kondisi fisik perusahaan mencerminkan kemampuan perusahaan. Demikian pula mengikuti bisnis proses perusahaan, mulai dari pembelian bahan baku, proses produksi, sampai pada pemasarannya, juga akan memberikan gambaran keadaan bisnis kreditur. Selain itu, kualitas para pegawai, konsepkonsep berpikir dan cara kerja seluruh staf perusahaan, juga akan memberikan gambaran masa depan perusahaan. Hal yang tidak kalah penting yaitu produk, dalam hal ini desain, teknologi, kegunaan, kemudahan, dan nilai, semuanya akan memberikan nilai tambah dalam evaluasi kreditur. Oleh karena itu, kreditur tidak saja berpedoman pada masalah angka laba, tetapi juga mengevaluasi kemampuan debitur secara komprehensif.

\section{METODE PENELITIAN}

Pemilihan metode yang sesuai dengan perumusan masalah akan menghasilkan kualitas penelitian yang valid. Sesuai dengan rumusan masalah mengenai bagaimanakah debitur dan kreditor memaknai manajemen laba atas laporan keuangan untuk pengajuan kredit perbankan, maka metode yang digunakan ialah unobtrusive observation seperti yang dilakukan oleh Alison et al. (2001). Hal ini dimungkinkan karena peneliti mempunyai akses bebas di tempat obyek studi. Tanpa akses seperti demikian, maka peneliti tidak mampu mengungkap praktik nyata manajemen laba (Dechow \& Skinner, 2000). Akan tetapi, karena masalah yang akan diungkap demikian peka dan demi menjaga masalah kerahasiaan, maka proses penelitian harus secara tersembunyi.

Proses pengumpulan datanya dilakukan dengan mendapatkan data langsung terkait dengan proses akuntansi sampai dengan penerbitan laporan keuangan untuk keperluan dimaksud. Hal ini sekaligus melakukan observasi tersembunyi selama proses kredit berlangsung sampai terjadinya keputusan kreditur memberi pembiayaan kredit. Adapun informan yang akan diwawancarai, antara lain:

1. Akuntan, sebagai manajemen dari pihak debitur yang terlibat dalam proses penyusunan dan penentuan kebijakan atas metode laporan keuangan.

2. Pihak kreditur, yaitu pihak yang bertugas sebagai analisi reviewer, staf analis kredit, dan relationship manager.

Pemilihan para informan tersebut di atas dilakukan secara sengaja, berdasarkan kriteria yang dijelaskan oleh Bungin (2007), bahwa informan merupakan individu yang telah cukup lama dan intensif menyatu dengan kegiatan atau medan aktivitas yang menjadi sasaran penelitian. Informan tidak hanya sekedar tahu dan dapat memberikan informasi, tetapi juga telah menghayati secara sungguh-sungguh hal-hal yang diteliti sebagai akibat dari keterlibatannya yang cukup lama dengan lingkungan atau kegiatan yang bersangkutan.

\section{Tabel 1. Informan Penelitian}

\begin{tabular}{ll}
\hline \multicolumn{1}{c}{$\begin{array}{c}\text { Identitas } \\
\text { Informan }\end{array}$} & \multicolumn{1}{c}{$\begin{array}{c}\text { Bidang Pekerjaan/Posisi/Jabatan dalam } \\
\text { Organisasi }\end{array}$} \\
\hline $\begin{array}{l}\text { Debitur: } \\
\text { 1. Yeremia }\end{array}$ & $\begin{array}{l}\text { Asisten Accounting Manager, PT ABC di } \\
\text { Surabaya yang bertanggungjawab pada } \\
\text { Accounting Manager. }\end{array}$ \\
2. Dewi & Staf Accounting di PT ABC Surabaya. \\
\hline Kreditur: & Kepala reviewer di Bank NN Surabaya \\
3. Buyung & $\begin{array}{l}\text { Sebagai salah satu kreditur dari PT ABC. } \\
\text { Realitionship Manager, di Bank NN }\end{array}$ \\
4. Doddy & $\begin{array}{l}\text { Surabaya sebagai salah satu kreditur dari PT } \\
\text { ABC. }\end{array}$ \\
Stafofficer, di Bank NN Surabaya sebagai \\
5. Sheldyn
\end{tabular}

Hal-hal yang diobservasi dan didiskusikan melalui wawancara mendalam terkait dengan debitur meliputi makna manajemen laba, manfaat, tujuan, motivasi, dan teknik melakukannya. Dengan pihak kreditur, selain hal tersebut juga dievaluasi teknik 
evaluasi yang digunakan sebagai dasar pengambilan keputusannya. Selanjutnya data diinterpretasikan dengan teknik content analysis (Bungin, 2007). Dengan memahami makna diskusi, mengikuti proses akuntansi dan proses evaluasi pemberian kredit, serta membandingkannya makna manajemen laba dari para peneliti sebelumnya, maka peneliti dapat menarik kesimpulannya.

\section{HASIL PENELITIAN DAN PEMBAHASAN}

\section{Manajemen Laba dalam Persepsi Debitur dan Kreditur}

Menurut Schipper (1989), manajemen laba adalah suatu intervensi yang disengaja pada proses pelaporan keuangan eksternal dengan maksud mendapatkan keuntungan pribadi. Senada dengan Schipper, Yeremia dan Dewi mengungkapkan pendapat dengan bunyi serupa. Sebagai asisten manajer akuntansi Yeremia mengerti betul atas kebijakan akuntansi yang dipilih atasannya, namun tidak dengan dasar atau alasan mengapa kebijakan atau metode tersebut yang digunakan.

"Manajemen laba sama dengan seni mengutakatik angka, yaitu angka pendapatan dan beban. Manajemen laba buka topik baru. Tidak usah melihat pada PT ABC, banyak perusahaan lain yang juga melakukan manajemen laba dengan berbagai motivasi. Contohnya, saya pernah tahu seorang teman yang memiliki perusahaan melakukan manajemen laba dengan motivasi pajak yang akan dibayar lebih kecil. Menurut saya, manajemen laba adalah hal yang wajar dalam praktik bisnis saat ini, asal dilakukan masih dalam tahap wajar. Wajar dalam arti tidak merugikan pihak lain."

Sementara itu, Dewi seorang staf akuntan mengungkapkan bahwa:

"Manajemen laba sama dengan upaya manajer untuk mempengaruhi angka laba yaitu dengan menaikkan atau menurunkan pos tertentu. Buat saya, manajemen laba bukan hal yang baru, namun dalam praktiknya saya kurang mengerti alasan apakah yang mendasari manajemen melakukan manajemen laba, karena terus terang ... saya tidak begitu paham dan seringkali saya hanya menjalankan perintah. Toh ... nanti kalau ada apa-apa ya tetap bos yang bertanggungjawab."

Scott (2006) berpendapat, bahwa praktik manajemen laba timbul karena adanya perilaku oportunis manajer. Terjadinya manajemen laba sepenuhnya di bawah wewenang manajer dan seringkali seorang staf akuntansi hanya melakukan perintah manajer tanpa memikirkan mengapa dan bagaimana dampaknya atas keputusan tersebut. Pendapat Scott inilah yang semakin menguatkan pendapat Dewi.

Persepsi berbeda diungkapkan oleh Doddy sebagai relationship manager yang telah menangani pemberian kredit perbankan terhadap PT ABC selama belasan tahun. Ia berpendapat:

"Sudah banyak perbincangan mengenai manajemen laba dari tahun ke tahun ... dan manajemen laba sudah semakin biasa ditemui di perusahaan-perusahaan. Manajemen laba sama dengan maksimalisasi laba baik melalui investasi, laba yang ditahan, maupun praktik lainnya yang dapat meningkatkan penghasilan perusahaan. Dalam proses pertimbangan keputusan kredit, saya tidak peduli apakah manajer melakukan manajemen laba atau tidak dan saya tidak perlu tahu mengapa manajer menaikkan atau menurunkan pos tertentu. Bagi saya yang terpenting kondisi di lapangan karena akan terlalu memusingkan ketika saya menganalisa laporan keuangan saya harus berpikir atas praktik manajemen laba yang dilakukan manajer."

Pernyataan Doddy ini menunjukkan bahwa kondisi di lapangan yang akan menentukan bukan analisa atas laporan keuangan. Pernyataan Doddy ini diperkuat dengan pendapat yang dikemukan oleh Buyung sebagai kepala analis kredit (reviewer) pada bank yang merupakan salah satu kreditur dari PT ABC, Buyung berpendapat:

"Manjemen laba merupakan upaya manajer mengelola laba melalui pos-pos yang ada dalam laporan keuangan sampai menghasilkan angka laba yang diinginkan manajer. Dalam proses pengajuan kredit, saya rasa praktik manajemen laba banyak terjadi. Namun, ada atau tidaknya praktik manajemen laba seharusnya tidak menjadi masalah bagi kreditur. Prinsip saya dalam proses persetujuan kredit, saya tidak boleh mempercayai informasi yang diberikan oleh debitur begitu saja. Saya selalu mencari informasi lain yang dapat mendukung atau mebandingkan dengan kondisi di lapangan. Dengan demikian saya bisa mendapatkan gambaran yang lebih de-kat atas kondisi keuangan debitur. Hal ini penting karena jika terjadi kredit macet atas fasilitas yang saya setujui, maka saya juga ikut bertanggung jawab."

Dari pernyataan kedua orang tersebut, tersirat jelas bahwa praktik manajemen laba tidak menjadi 
masalah bagi kreditur dalam proses pengambilan keputusan kredit. Laporan keuangan merupakan informasi ekonomi yang fundamental namun kondisi di lapangan yang menjadi tolak ukur atas kondisi ekonomi perusahaan yang sebenarnya.

Sheldyn sebagai staf officer yang bertugas mengurus dokumen-dokumen persyaratan kredit PT ABC mengungkapkan pengalamannya saat menganalisa laporan keuangan PT ABC.

"Saya tidak menaruh curiga atau melihat kejanggalan atas atas informasi yang ada dalam laporan keuangan. Saya hanya memasukan angka-angka tersebut dalam formula analisis rasio keuangan sesuai standar perbankan. Hasil dari analisis kuantitatif tersebut saya berikan pada Pak Buyung untuk ditelaah lebih lanjut. Namun, Pak Buyung menemukan beberapa kejanggalan atas angka-angka dalam pos tertentu laporan keuangan tersebut. Ia merasa kenaikan beberapa pos tersebut tidak masuk akal. Akhirnya saya menanyakan kenaikan tersebut pada salah satu staf akuntan yang terlibat dalam proses penyusunan laporan keuangan."

Sekilas dari pendapat para informan di atas, dapat dilihat bahwa pengalaman menunjukkan bahwa kreditur harus waspada atas praktik manajemen laba. Manajemen laba semata-mata dilakukan manajer untuk kepentingan perusahaan dalam memperoleh kredit. Laporan keuangan sebagai alat dalam menyajikan informasi atas kinerja perusahaan digunakan dengan kinerja perusahaan yang sehat diharapkan dapat mendukung proses pengajuan kredit tersebut untuk mendapatkan persetujuan.

Strategi menaikkan atau menurunkan laba melalui pos-pos akuntansi yang ada dalam laporan keuangan. Kondisi ini sesuai dengan prinsip hati-hati yang menjadi dasar kreditur dalam melakukan analisa kredit. Kreditur tidak hanya dituntut untuk bersikap peka namun juga berhati-hati dalam menganalisa informasi yang didapat dari debitur. Demikian juga informasi dalam laporan keuangan yang tidak sepenuhnya dapat dipercaya mengingat motivasi tertentu yang dimiliki debitur serta sifat terbatas yang dimiliki laporan keuangan.

\section{Persepsi mengenai Manajemen Laba}

Telah banyak kontroversi mengenai manajemen laba apakah sama dengan manipulasi laba. Beberapa pihak merasa dirugikan dengan adanya praktik manajemen laba demikian pihak sebaliknya. Djakman (2003) mengungkapkan bahwa, manajemen laba (earnings management) yang dilakukan melalui manajemen akrual tidak sama dengan manipulasi laba (earnings manipulation) karena manajemen laba yang dilakukan hanya memanfaatkan kelemahan inheren dari kebijakan akuntansi akrual dan masih berada dalam koridor prinsip akuntansi berterima umum. Manipulasi laba merupakan tindak pelanggaran terhadap prinsip akuntansi berterima umum untuk menghasilkan kinerja keuangan perusahaan sesuai kepentingan manajer atau perusahaan (Schroeder \& Clark, 1998). Berikut ini adalah pendapat Yeremia:

"Saya pikir manajemen laba tidak sama dengan manipulasi labak karena praktik manjemen laba masih ada dalam koridor standar akuntansi. Lain halnya ketika manajemen laba yang dilakukan sudah pada manipulasi angka, maka tindakan tersebut dapat dikatakan manipulasi laba. Manajemen laba hanya mempermainkan angka laba melalui metode akuntansi. sama halnya waktu di kuliah dulu. Kita ditekankan bahwa metode persediaan LIFO dapat menghasilkan angka laba yang lebih besar dibandingkan dengan metode persediaan AVERAGE atau FIFO. Apakah itu sama dengan manipulasi laba? Menurut saya, manajer atau akuntan dalam melakukan manajemen laba pasti mempunyai alasan atau dasar atas keputusan itu. Selain itu, SAK juga memberikan kebebasan untuk memilih metode atau kebijakan akuntansi sesuai dengan karakteristik perusahaan. Manipulasi laba terjadi ketika saya memanipulasi angka secara sengaja beserta dokumen pendukungnya."

Pernyataan Yeremia yang mewakili persepsi dari manajemen PT ABC yang menunjukkan bahwa di mata debitur praktik manajemen laba bukanlah tindak kecurangan atau manipulasi sepanjang dilakukan dalam koridor standar akuntansi, karena standar akuntansi dipandang sebagai norma-norma yang diyakini tidak akan menghasilkan informasi yang menyesatkan bagi pengguna laporan keuangan. Hal ini juga didukung dengan pendapat dari Dian yang sebagai seorang dosen ia diharapkan memberikan pendapat yang lebih konseptual.

Pandangan debitur ini juga didukung dengan pernyataan dalam Standar Audit Seksi 316 IAI tahun 2001 mengenai kecurangan yaitu:

Kecurangan berbeda dengan kekeliruan. Faktor yang membedakan antara kecurangan dan kekeliruan adalah apakah tindakan yang mendasarinya, yang berakibat terjadinya salah saji dalam laporan keuangan, berupa tindakan yang disengaja atau tidak disengaja. Kecurangan dalam pelaporan keuangan dapat berupa penghilangan 
secara sengaja atas jumlah atau pengungkapan dalam laporan keuangan untuk mengelabuhi pemakai laporan keuangan, yang menyangkut tindakan manipulasi, pemalsuan, perubahan catatan akuntansi, termasuk kesalahan penerapan secara sengaja prinsip akuntansi yang berkaitan dengan jumlah, klasifikasi, cara penyajian, atau pengungkapan."

Penelitian terdahulu mengenai manajemen praktik pajak oleh Kurniawan diungkapkan bahwa praktik manajemen laba oleh manajer pada hakikatnya tidak berbeda dengan praktik manajemen pajak yang dilakukan oleh wajib pajak. Menurutnya, manajemen pajak bukanlah tindak kecurangan sepanjang dilakukan secara legal dalam koridor UU dan peraturan perpajakan. Manajemen pajak bukan tindakan koruptif, karena wajib pajak hanya menyiasati kelemahankelemahan yang ada dalam UU maupun peraturan perpajakan.

Jika kelemahan dalam peraturan perpajakan tidak ditemukan oleh wajib pajak, biasanya wajib pajak menyiasati penerapan akrual yang diperbolehkan dalam akuntansi perpajakan, sehingga jika dilihat bahwa manajemen laba yang dilakukan tanpa melanggar standar akuntansi pada prinsipnya adalah legal. Kecuali, jika manajer atau akuntan dengan sengaja melakukan manipulasi perhitungan atau angka dari pos tertentu. Hal ini juga dikuatkan dengan pendapat dari Kurniawan yang memberikan pandangan soal pajak.

"Pada hakikatnya, manajemen pajak adalah upaya-upaya untuk memperkecil pajak terutang dengan cara memperkecil laba kena pajak sedemikian rupa. Manajemen laba adalah upayaupaya manajer untuk memperkecil risiko dirinya atau risiko perusahaan dengan cara mencapai angka laba tertentu yang sesuai dengan tujuannya." bahwa:

Dari perpektif berbeda Buyung mengungkapkan

"Sudah merupakan hal yang wajar jika perusahaan melalui laporan keuangan ingin menunjukkan kinerja perusahaan yang sehat Menurut saya PT ABC ada kecenderungan praktik manajemen laba. Kondisi ini terjadi saya mengalisa laporan keuangan tahunan PT ABC, ada beberapa pos yang menunjukkan kenaikan yang tidak wajar jika dibandingkan dengan kenaikkan tahun-tahun sebelumnya. Namun, sampai saat ini saya masih belum mendapatkan jawaban yang memuaskan. Penyesuaian audit yang belum disesuaikan info yang dari manajemen. Akibatnya, saya menilai kondisi ini bisa saja merupakan kesengajaan manajer atau akuntan pada proses pelaporan keuangan eksternal. Tentu saja dengan tujuan agar kredit yang diajukan bisa lolos, diperpanjang atau untuk tujuan penambahan fasilitas kredit."

"Manajemen laba mengakibatkan kualitas laporan keuangan menjadi menurun, selain itu dapat menyesatkan pengguna informasi laporan keuangan. Laporan keuangan yang mengandung manajemen laba ditakutkan tidak menggambarkan kondisi perusahaan yang sebenarnya. Kondisi ini tidak jauh berbeda dengan melakukan kebohongan public terutama untuk perusahaan yang go public sehingga menurut saya sama saja dengan manipulasi laba. Oleh karena itu, saya melakukan analisis atas laporan keuangan debitur saya selalu bandingkan dengan kondisi di lapangan. Kita sebagai kreditur menjadi memiliki pemikiran yang lebih dahulu curiga agar atas debitur kita karena kenyataannya informasi dalam laporan keuangan tidak dapat sepenuhnya dipercaya. Apalagi tidak semua orang bisa membaca laporan keuangan dengan memiliki "feeling" untuk melihat adanya tindakan manajemen laba atau manipulasi laba."

Persepsi Buyung ini diperkuat dengan pendapat dari Iren sebagai salah satu Senior Auditor di KAP ternama di Surabaya. Ia mengungkapkan saat melakukan tugas audit manajemen seringkali turut campur dalam mempengaruhi pemeriksaan KAP dengan berbagai alasan atau dasar tertentu. Manajemen laba hanya diperhalus secara istilahnya. Iren mengatakan:

"Saat melakukan penyesuaian audit atas laporan keuangan PT X pihak perusahaan malah yang menentukan. Pernah pengalaman saya, pimpinan perusahaan secara gambling mengungkapkan bahwa ia ingin angka terakhir retained earning berakhir dengan 888 . Karena menurut kepercayaannya itu angka hoky perusahaan. Pengalaman itu membuat saya heran. Namun, tetap saja ... kami melakukan apa saja yang perusahaan minta."

Pandangan Buyung ini juga dikuatkan dengan pernyataan IAI tahun 2007 dalam Kerangka Dasar Penyusunan Penyajian Laporan Keuangan paragraf 16 berkaitan dengan netralitas laporan keuangan sebagai berikut:

"Informasi harus diarahkan pada kebutuhan umum pengguna, dan tidak bergantung pada kebutuhan dan keinginan pihak tertentu. Tidak boleh ada usaha untuk menyajikan informasi yang menguntungkan beberapa pihak, sementara hal tersebut akan merugikan pihak lain yang mempunyai kepentingan yang berlawanan." 
Lain halnya dengan Buyung, menurut pandangan Doddy manajemen laba bukanlah suatu bentuk perekayasa laporan keuangan.

"Jika ingin melihat kondisi perusahaan yang sesungguhnya haruslah melihat pada kinerja perusahaan minimum lima tahun berjalan bukan hanya pada laporan keuangan atau secara aktual. Karena laporan keuangan hanya serangkaian laporan pada periode pendek sehingga tampak seperti permainan angka, apalagi kondisi saat ini KAP tidak memiliki peran sebesar dulu. Dulu ... laporan keuangan yang ada cap dari KAP ternama tidak perlu kita cek lagi, seakan-akan memiliki kekuatan. Sekarang sudah tidak mempunyai kekuatan itu lagi. Sama halnya laporan keuangan PT ABC meski sudah cap dari KAP ternama tetap harus dicek ulang. Apa yang disajikan dalam laporan keuangan sesuai atau tidak dengan kondisi dilapangan. Jika ada yang janggal baru kita cari tahu lebih lanjut. Pengalaman saya hingga saat ini laporan keu-angan PT ABC masih dalam tahap wajar. Si bos juga terbuka dalam memberika informasi yang kita butuhkan. Namun, kita harus tetap hati-hati, harus bisa melihat masuk akal masuk akal atau tidak angka-angka yang disajikan, bukti-bukti pendukungnya dan kondisi dilapangan seperti apa. Intinya dalam kegiatan perkreditan, pihak krediturlah yang harus lebih pandai dalam melihat kondisi ekonomi debitur."

Pandangan Doddy ini juga dikuatkan dengan pendapat dari Suwardjono (2005) yang mengungkapkan bahwa manajemen laba bukanlah suatu hal merugikan selama dilakukan dalam koridor-koridor peluang, manajemen laba tidak selalu diartikan dengan proses manipulasi laporan keuangan karena terdapatnya beberapa pilihan metode yang dapat digunakan dan bukan sebagai suatu larangan. Manajemen laba berusaha untuk mengatur kondisi perusahaan dan sebagai usaha untuk mempengaruhi pihak-pihak yang berkepentingan dengan laporan keuangan. Pengaturan laba dapat saja dilakukan selama tidak mengaburkan atau menghilangkan informasi atau masih mencerminkan keadaan yang sebenarnya terjadi pada perusahaan.

Fenomena manajemen laba memang sangat kental dalam dunia akuntansi atau bisnis. Hal ini tampak dari beberapa pengalaman informan di atas. Berbagai motivasi, mendorong manajemen melakukan manajemen laba. Hal ini mengakibatkan kreditur tidak lagi mempercayai informasi keuangan yang diberikan oleh debitur. Persepsi atas praktik manajemen laba tiap-tiap orang berbeda. Buyung sebagai kreditur mengungkapkan bahwa manajemen laba merupakan kesengajaan manajemen yang dapat mengarah ke manipulasi laba. Yeremia dari pihak debitur mengungkapakan bahwa manajemen laba tidak dapat disamakan dengan manipulasi laba karena masih dalam koridor SAK. Jika dilihat baik dari debitur maupun kreditur tampak bahwa pendapat yang disampaikan terpengaruh oleh posisinya.

Tidak dapat dipungkiri bahwa praktik manajemen laba dapat mengarah pada manipulasi laba. Manajemen laba seringkali merugikan pihak eksternal sebagai pengguna atas infromasi keuangan itu. Manajemen laba dan manipulasi laba tidak jauh berbeda. Manajemen laba dapat dikatakan menipulasi laba ketika kondisi itu merugikan pihak lain.

\section{Pola Manajemen Laba oleh Debitur dan Usaha Kreditur dalam Mendeteksi Manajemen Laba.}

Seperti yang diungkapkan pada sebelumnya, praktik manajemen laba dapat dilakukan dengan empat pola yaitu manajemen akrual, penerapan suatu kebijakan, perubahan akuntansi sukarela, penerapan akuntansi wajib, melalui kebijakan operasi, investasi, dan pembelanjaan, (Wicaksono, 2011). Dalam mengungkapkan pola dari manajemen laba yang dilakukan oleh debitur, pihak debitur bersikap lebih tertutup. Ungkapan ini tampak dari pernyataan Yeremia yang hanya mengatakan bahwa manajer dan pihaknya hanya melakukan seperti pemilihan metode persedian LIFO, kemudian penggeseran waktu dari pendapatan atau beban jika dibutuhkan.

Sweeney (1994) mengevaluasi perubahan metode akuntansi dari 130 perusahaan yang melanggar perjanjian kredit. Perubahan metode akuntansi yang teridentifikasi adalah perubahan depresiasi, perubahan LIFO, FIFO, perubahan umur ekonomis aktiva, dan perubahan dalam alokasi biaya overhead. Penelitian Sweeney ini memberikan bukti bahwa manajer perusahaan merespon pemilihan metode akuntansi yang menaikkan laba dalam hal menghindari pelanggaran perjanjian utang, sehingga dalam proses pengungkapan pola manajemen laba ini peneliti menggunakan metode dokumentasi sebagai instrumen pendukung berupa coretan-coretan dari pihak manajer berkaitan dengan kebijakan akuntansi yang dipilih.

Dari pihak kreditur yaitu Buyung mengungkapkan berdasarkan pengalamananya beragam pola manajemen dalam melakukan manajemen laba. Namun, strategi manajemen yang paling banyak digu-nakan ialah menggeser biaya akrual diskresioner periode mendatang ke periode kini dan atau menggeser pendapatan akrual diskresioner periode kini ke periode mendatang (taking a bath) atau memaksimumkan atau menurunkan angka laba untuk tujuan tertentu. 
Adanya fleksibilitas dalam PSAK memungkinkan diskresi manajemen dalam akuntansi akrual. Dengan mempergunakan flesibilitas yang diperbolehkan oleh SAK, manajemen dapat melakukan earning manajemen. Dasar akrual dipandang lebih rasional dan wajar dibandingkan dengan dasar kas atau tunai. Penggunaan dasar akrual dimaksudkan agar laporan keuagan menjadi lebih informatif yaitu dapat mencerminkan keadaan yang sebenarnya, tetapi kenyataannya manajemen menggunakan discreation accrual untuk menaikkan atau menurunkan laba.

Kebijakan akrual dapat dibagi menjadi dua: (a) Akrual yang sewajarnya ada dalam laporan keuangan (nondiscreationary acrruals); dan (b) bagian akrual yang sengaja dilakukan manajemen untuk menaikkan atau menurunkan laba (discreationary accrual) (Schiper, 1989; Guidry et al., 1999; Pae, 1999).

\section{Dampak Manajemen Laba terhadap Peran Laporan Keuangan}

Terdapat perbedaan persepsi Buyung dan Doddy atas peran laporan keuangan dalam proses keputusan pemberian kredit. Buyung memandang laporan keuangan sebagai dokumen pertama yang harus dianalisis, sedangkan Doddy memandang laporan keuangan sebagai dokumen pelengkap pada posisi terakhir yaitu hanya untuk melengkapi sistem prosedural perbankan. Menurut persepsi Doddy dalam melakukan penilaian atas kondisi keuangan debitur yang menjadi sorotan pertama ialah karakter (character), kemudian jaminan (collateral), kapital (capital) dan menyusul "C" lainnya. Laporan keuangan digunakan ketika Bank Indonesia melakukan audit atas bank tempat informan bekerja, maka laporan keuangan itu digunakan sebagai dasar atas keputusan persetujuan pemberian kredit pada PT ABC. Untuk memperkuat pendapatnya Doddy memberikan perumpamaan:

"Ada seorang teman datang, ingin meminjam uang kita dengan menunjukkan saldo tabungan dia. Peran laporan digambarkan sama halnya dengan peran buku tabungan tersebut. Tidak mungkin saya akan memberikan pinjaman hanya dengan melihat buku tabungannya, melainkan melihat karakter, kondisi keuangan dari orang tersebut. Sama halnya dengan laporan keuangan, tidak bisa jika memandang laporan keuangan sebagai dokumen yang dapat digunakan sebagai bahan pertimbangan dalam menggambarkan kondisi ekonomi perusahaan. Laporan keuangan hanya sebagai dokumen pelengkap atas kondisi ekonomi debitur dilapangan. Laporan keuangan hanyalah untuk memenuhi sistem prosedural. Ketika Bank Indonesia melakukan audit maka saya bisa memberikan pertanggungjawaban atas dasar pemberian kredit yang saya berikan. Apa? Yaaa.. laporan keuangan tersebut. Saya memilih untuk melakukan analisis 5C yang akan diperkuat dengan data-data lainnya terkait kondisi ekonomi debitur. Baik dengan meninjau lokasi bisnis debitur, wawancara dengan debitur, konfirmasi ke pihak-pihak yang pernah menjalin bisnis dengan PT ABC, BI Checking, $B I$ Trade dan kemudian menganalisa masuk akal atau tidak informasi yang ia dapatkan. Setelah semua informasi tersebut dikumpulkan, maka saya mulai melakukan justifikasi dengan melihat karakter dari debitur apakah informasi yang debitur berikan disampaikan secara jujur dan terbuka."

Menurut Buyung peran laporan keuangan adalah yang utama. Data-data ekonomi melalui angkaangka dalam laporan keuangan menggambarkan kondisi ekonomi perusahaan.

"Sebagai reviewer, saya tidak boleh langsung percaya dengan angka-angka yang ada dalam laporan keuangan debitur. Melainkan, mencocokkan informasi akuntansi yang diberikan debitur dengan analisa 5C, yaitu melihat character dari debitur itu sendiri, histori dari debitur apakah ada berita yang tidak baik. Kemudian baru melihat pada collateral dan analisis C selanjutnya."

Dari pendapat kedua kreditur tersebut, dapat dilihat bahwa laporan keuangan masih memiliki peran sebagai bahan pertimbangan dalam persetujuan kredit. Namun, perbedaan pandangan peran laporan keuangan hanya dikarenakan cara pandang yang berbeda yang dipengaruhi oleh pengetahuan yang dimiliki, tujuan, siapa yang menafsirkan dan situasi serta kondisi disekitarnya. Ungkapan senada juga disampaikan oleh Schmidt \& Minssen (2007). Namun, interpretasi laba akuntansi sebagai teks, tidak dapat dilepaskan dari konteks, yaitu tergantung pada siapa yang menafsirkan, waktu, situasi, kepentingan atau tujuan pembacaan, pengetahuan, kebiasaan, pengalaman, serta latar belakang lainnya.

Hasil penelitian menunjukkan bahwa manajemen laba memang terjadi. Apabila kreditur hanya menitik beratkan pada evaluasi kuantitatif (analisa laporan keuangan) saja, maka kreditur akan menolak apabila mengetahui debitur melakukannya. Hal demikian karena secara teoritis pihak kreditur mamahami bahwa manajemen laba merubah fenomena nyata sebuah kemampuan perusahaan. Akan tetapi karena 
kreditur juga menerapkan analisa kualitatif, yaitu meliputi analisa character (watak), capacity (kemampuan), capital (modal), collateral (jaminan), dan economics condition (kondisi ekonomi) atau yang lazim disebut analisa 5 C (Suyatno, 1993), maka kreditur mempunyai informasi yang lebih komprehensif, sehingga berani menomorduakan masalah manajemen laba. Dengan melakukan evaluasi 5 C, kreditur mampu membuat keputusan yang tepat sesuai dengan tujuan pembiayaan kredit serta perhitungan risiko yang mungkin akan terjadi.

\section{SIMPULAN DAN SARAN}

Berbagai persepsi manajemen laba telah diungkapkan menurut padangan baik dari sisi debitur dan kreditur. Pada umunya debitur memandang manajemen laba sebagai upaya manajer untuk mengelola angka laba sampai pada angka yang diinginkan melalui kebijakan dan metode akuntansi. Kebebasan untuk memilih metode akuntansi oleh SAK dianggap sebagai peluang yang memang bisa dimanfaatkan. Dengan begitu, manajemen laba bukanlah tindakan kecurangan atau manipulasi laba karena masih dilakukan dalam koridor SAK. Sama halnya dengan praktik manajemen laba yang dilakukan akuntan PT ABC.

Pandangan yang berbeda muncul dari Buyung sebagai pihak kreditor, ia mengungkapkan bahwa manajemen laba bisa dikatakan sebagai manipulasi laba. Hal ini dikarenakan dengan melakukan manajemen laba yang dilakukan PT ABC dapat memberikan informasi dalam laporan keuangan yang menyesatkan para pembacanya sehingga tidak lagi memenuhi kepentingan pengguna melainkan lebih menitik-beratkan pada kepentingan manajemen. Namun, kedua belah pihak pada dasarnya mengerti bahwa ma-najemen laba bukanlah hal yang baru dan hampir semua perusahaaan di Indonesia ini melakukan manajemen laba. Hal ini dapat dilihat pada penelitian terdahulu yang telah banyak dilakukan sebelumnya.

Dampak atas praktik manajemen laba atas laporan keuangan dalam proses pengajuan kredit PT ABC tidak terlalu besar. Hal ini dikarenakan kreditur mempunyai penilaian yang lain selain dari laporan keuangan, yaitu melalui analisis kualitatif sebagai bahan pertimbangan dalam memutuskan pemberian kredit. Selain itu kreditur sadar bahwa pihaknya harus lebih berhati-hati sehingga dalam menerima informasi keuangan pihaknya tidak langsung mempercayai informasi tersebut melainkan melakukan berbagai verifikasi atau konfirmasi dengan pihak ke tiga sebagai cocokan. Analisis kualitatif yaitu analisis 5C membantu kreditur untuk lebih mendapatkan gambar- an lebih dalam atas kondisi ekonomi debitur. Character dipandang sebagai point utama yang harus dinilai oleh kreditur. Mengapa? karena karakter dipandang sebagai unsur yang menentukan seseorang ber-sikap. Dengan karakter yang baik, maka keterbukaan akan informasi menjadi lebih mudah, itikad baik, dan kejujuran.

Praktik manajemen laba mengakibatkan kreditur tidak lagi sepenuhnya mempercayai informasi dalam laporan keuangan meskipun telah diperiksa KAP ternama. Bahkan posisi laporan keuangan dalam proses analisis menjadi rancu. Buyung memandang laporan keuangan sebagai acuan dalam melihat kondisi ekonomi debitur di lapangan. Doddy memandang laporan keuangan sebagai dokumen pelengkap untuk memenuhi system prosedur yang ditetapkan Bank Indonesia. Dari dua kondisi ini dapat dilihat bahwa peran laporan keuangan tidak lagi sebagai dokumen yang utama.

\section{DAFTAR REFERENSI}

Alison, L., Snook, B., \& Stein, K. L. 2001. Unobtrusive Measurement: Using Police Information for Forensic Research. Qualitative Research, 1(2): 241-254.

Altman, E. I. 1968. Financial Ratios, Discriminant Analysis and the Prediction of Corporation Bankruptcy. The Journal of Finance, 23(4): 589-609.

Andriyani, L. 2004. Indikasi Manajemen Laba Selama Perjanjian Kontrak Utang Studi Empiris Pada BUMN. Tesis Tidak Dipublikasikan. Program Pascasarjana Ilmu Akuntansi. Universitas Gadjah Mada. Yogyakarta.

Ayres, F. L. 1994. Perceptions of Earnings Quality: What Managers Need to Know. Management Accounting, 75(9): 27-29.

Beaver, W. H. 1966. Financial Ratio as Predictors of Failure. Journal of Accounting Research, 4 (Empirical Research in Accounting: Selected Studies 1966): 71-111.

Brigham, E. F. \& Gapenski, L. C. 1993. Intermediate Financial Management. Fourth Edition. Orlando, FL: The Dryden Press.

Bungin, B. 2007. Penelitian Kualitatif: Komunikasi, Ekonomi, Kebijakan Publik dan Ilmu Sosial. Jakarta: Kencana Prenama Media Group.

DeAngelo, H., DeAngelo, L., \& Skinner, D. J. 1994. Accounting Choice in Troubled Companies. Journal of Accounting and Economics, 17(1): 113-143.

Dechow, P. M. \& Skinner, D. J. 2000. Earning Management: Reconciling the Views of Accounting Academics, Practitioners, and Regulator. Accounting Horizons 14(2): 235-250. 
DeFond, M. \& Jiambalvo, J. 1994. Debt Covenant Violations and Manipulation of Accruals. Journal of Accounting and Economics, 17(1): 145176.

Djakman, C. D. 2003. Manajemen Laba dan Pengaruh Kebijakan Multi Papan Bursa Efek Jakarta. Makalah Simposium Nasional Akuntansi VI. Surabaya, 16-17 Oktober 2003: 141-162.

Fischer, M. \& Rosenzweig, K. 1995. Attitude of Students and Accounting Practitioners Concerning The Ethical Acceptability of Earnings Management. Journal of Business Ethics, 14(6): 433444.

Gosh, S. 2010. Creative Accounting: A Fraudulent Practice Leading to Corporate Collapse. Research and Practice in Social Sciences, 6(1): 1-15.

Guidry, F., Leone, A. J., \& Rock, S. 1999. Earningsbased Bonus Plans and Earnings Management by Business-unit Managers. Journal of Accounting and Economics, 26(1-3): 113-142.

Healy, P. M. \& Wahlen, J. M. 1999. A Review of The Earnings Management Literature and Its Implications for Standard Setting. Accounting Horizons, 13(4): 365-383.

Horrigan, J. O. 1965. Some Empirical Bases of Financial Ratio Analysis. Accounting Review, 40 (3): 558-569.

Ikatan Akuntan Indonesia. 2009. Standar Akuntansi Keuangan per 1 Juli 2009. Jakarta: Penerbit Salemba Empat.

Jaggi, B. \& Lee, P. 2002. Earnings Management Response to Debt Covenant Violations and Debt Restructuring. Journal of Accounting, Auditing \& Finance, 17(4): 295-324.

Jiambalvo, J. 1996. Discussion of Causes and Con sequenses of Earnings Manipulation: An Ana lysis of Firms Subject to Enforcement Actions by the SEC. Contemporary Accounting Research, 13(1): 37-47.

Jusuf, J. 2010. Analisis Kredit untuk Account Officer. Jakarta: Garmedia Pustaka Utama.

Kotler, P. \& Keller, K. L. 2011. Marketing Management. $14^{\text {th }}$ Edition. New Jersey: Prentice Hall.

Kusumawati, A. A. N. \& Sasongko, N. 2005. Analisis Perbedaan Pengaturan Laba (Earnings Management) pada Kondisi Laba dan Rugi pada Perusahaan Manufaktur di Indonesia. Jurnal Akuntansi dan Keuangan, 4(1): 1-20.

Leuz, C., Dhananjay, N., \& Wysocki, P. D. 2003. Earnings Management and Investor Protection: An International Comparison. Journal of Financial Economics, 69(3): 505-527.

Lev, B. 1989. On the Usefulness of Earnings and Earnings Research: Lessons and Directions from Two Decades of Empirical Research. Journal of Accounting Research, 27(3): 153-193.
McNichols, M. \& Wilson, G. P. 1988. Evidence of Earnings Management from the Provision for Bad Debts. Journal of Accounting Research, 26(Supplement): 1-31.

Mulford, C. W. \& Comiskey, E. E. 2002. The Financial Numbers Game: Detecting Creative Accounting Practices. NY: John Wiley \& Sons.

Pae, J. 1999. Earnings Management and Its Impact on the Information Content of Earnings and the Properties of Analysts Forecasts. Thesis. Published. UMI.

Palliam, R. \& Shalhoub, Z. 2003. The Phenomenology of Earnings Management within the Confines of Agency Theory. International Journal of Value-Based Management, 16(1): 75-88.

Peltier-Rivest, D. 1999. The Determinants of Accounting Choices in Troubled Companies. Quarterly Journal of Business and Economics, 38(4): $28-44$.

Riduwan, A. 2010. Etika Perilaku Koruptif dalam Praktik Manajemen Laba: Studi Hermeneutika.Working Paper in Accounting and Finance. Department of Accounting. Surabaya: STESIA.

Rosner, R. L. 2003. Earnings Manipulation in Failing Firms. Contemporary Accounting Research, 20 (2): 361-408.

Saleh, N. M. \& Ahmed, K. 2005. Earnings Management of Distressed Firms during Debt Renegotiation. Accounting and Business Research, 35(1): 69-86.

Schipper, K. 1989. Commentary on Earnings Management. Accounting Horizons, 3: 91-102.

Schmidt, S. \& Minssen, H. 2007. Accounting for International Assignments: The Case of the German Chemical Industry. Journal of Human Resource Costing and Accounting, 11(3): 214-228.

Schroeder, R. G. \& Clark, M.W. 1998. Accounting Theory: Text and Reading. Sixth Edition. New York: John Wiley \& Sons.

Scott, W. R. 2006. Financial Accounting Theory. 4th Edition. Canada: Person Education.

Sharma, V. D., Sharma, D. S., \& Ananthanarayanan, U. 2011. Client Importance and Earnings Management: The Moderating Role of Audit Committees. AUDITING: A Journal of Practice \& Theory, 30(3): 125-156.

Sugiri, S. 1998. Earning Management: Teori, Model dan Bukti Empiris. Jakarta.

Surifah. 1999. Informasi Asimetri dan Pengaruh Manajemen Terhadap Pelaporan Keuangan dalam Perspektif Agency Theory. Kajian Bisnis, 17: 71-81.

Sutojo, S. 2000. Seri Manajemen Bank No. 6 - Strategi Manajemen Kredit Bank Umum: Konsep, Teknik dan Kasus. Jakarta: Damar Mulia Pustaka. 
Suwardjono. 2005. Teori Akuntansi: Perekayasaan Pelaporan Keuangan. Edisi Ketiga. Jogjakarta: BPFE.

Suyatno, T. 1993. Dasar-Dasar Perkreditan Perbankan. Jakarta: PT Gramedia.

Sweeney, A. 1994. Debt Covenant Violations and Managers' Accounting Responses. Journal of Accounting and Economics, 17(3): 281-308.

Syam, H. 2004. Earnings Management untuk Meningkatkan Kinerja Pada Perusahaan Yang Mengalami Financial Distress Studi Empiris Pada Perusahaan Public Yang Terdaftar di Bursa Efek Jakarta. Tesis Tidak Dipublikasikan.
Program Pascasarjana Ilmu Akuntansi. Universitas Gadjah Mada. Yogyakarta

Teoh, S. H., Welch, I., \& Wong, T. J. 1998. Earnings Management and The Underperformance of Seasoned Equity Offerings. Journal of Financial Economics, 50(1): 63-99.

Wicaksono, B. B. 2011. Pengaruh Karakteristik Perusahaan Terhadap Luas Pengungkapan Sukarela Pada Laporan Keuangan. Skripsi. Tidak Dipublikasikan. Universitas Diponegoro, Semarang.

Worthy, J. C. 1984. Shaping an American Institution: Robert E. Wood and Sears, Roebuck. Urbana: University of Illinois. 